\title{
CAN THE POLICE USE WEAPONS IN CASES OTHER THAN LEGITIMATE DEFENCE? A COMPARATIVE STUDY WITH THE FRENCH EXAMPLE
}

\author{
M. Buhari ÇETINKAYA*
}

\section{ABSTRACT}

Law enforcement forces are authorized to the use of weapons in accordance with their duties. The use of the body-targeted weapons conflicts with the right to life and body integrity. The limits of this authority, which conflicts with the most valuable rights, should be determined very well. Law enforcement forces should exercise this authority within the framework of criteria and instructions that leave no room for doubt. Events that took place in Turkey, in 2014, the terrorist attacks that took place in France, in 2015 and 2016 have led to the re-opening of discussion on these authorities.

Law enforcement forces is equipped with the authority to the use of weapons within the framework of their duty to maintain public order. This authority is related to the authorization of the law. Additionally, in connection with its public duty, they are obliged to prevent attacks that will take place within the context of preventive activities it carries out. This is also related to the legitimate defence. The authorization of the law implies a broader concept than legitimate defence. The French legislator, considering that the powers of the national police are insufficient in the face of the attacks that took place in recent years, evaluated the authority to the use of weapons in a different framework. Evaluating the perspective of the actuality condition of the legitimate defence broader, can lead to a broader concept than the legitimate defence. It can be also concluded that the concept of legitimate defence has not been abandoned due to the fact that the necessity and proportionality conditions of legitimate defence has become much stricter.

In this study, we will examine how the new French framework law related to the use of weapons establishes a legitimate defence concept specific to the law enforcement forces. In this direction, we will consider the situation in Turkish law.

Keywords: Authority to the use of weapons, preventive actions, legitimate defence, authorization of the law, lawfulness.

* Dr., Research Assistant, Istanbul University Law Faculty Criminal Law and Criminal Procedure Law Department/ ISTANBUL, e-mail: buharicetinkaya@istanbul.edu.tr,

ORCID : 0000-0003-0996-5055.

DOI : 10.34246/ahbvuhfd. 933626

Yayın Kuruluna Ulaştığı Tarih

: $19 / 02 / 2021$

Yayınlanmasının Uygun Görüldüğ̈̈ Tarih: 26/04/2021

Ankara Hacı Bayram Veli Üniversitesi Hukuk Fakültesi Dergisi C. XXV, Y. 2021, Sa. 2869 


\section{POLİS MEŞRU SAVUNMA HALİ DIŞINDA SILAH KULLANABİLIR Mİ? FRANSIZ ÖRNEĞİ İLE MUKAYESELİ BİR İNCELEME}

\section{$\ddot{O} Z$}

Kolluk kuvvetleri vazifeleri gereği silah kullanma yetkisi ile donatılmışlardır. Kolluğun bedene yönelik silah kullanması, yaşam hakkı ve vücut dokunulmazlı̆̆ ile çatışmaktadır. En değerli haklarla çatışan bu yetkinin sınırlarının çok iyi belirlenmesi gerekmektedir. Kolluk bu yetkiyi şüpheye yer birakmayacak kriterler ve talimatlar çerçevesinde kullanmalıdır. Türkiye'de 2014 yılında gerçekleşen olaylar, Fransa'da 2015 ve 2016 yıllarında gerçekleşen terör saldırıları kolluğun bu yetkisinin yeniden tartışmaya açılmasına sebep olmuştur.

Kolluk kendisine verilen, kamu düzenini koruma görevi çerçevesinde silah kullanma yetkisi ile donatılmıştır. Bu yetki kanunun hükmünü yerine getirme ile alakalıdır. Yine bununla bağlantılı şekilde kolluk, yürüttüğ̈̈ önleyici faaliyetler bağlamında gerçekleşecek saldırlları engellemekle yükümlüdür. Bu da meşru savunma ile alakalıdır. Kanunun hükmünü yerine getirme, meşru savunmadan daha geniş bir konsepti ifade eder. Fransız yasa koyucusu, son yıllarda gerçekleşen saldırlar karşısında özellikle ulusal polisin yetkilerinin yetersiz olduğu düşüncesiyle silah kullanma yetkisini farklı bir çerçevede ele almıştır. Meşru savunmanın mevcudiyet şartının daha geniş bir bakış açısıyla ele alınmasından, yeni çerçevenin meşru savunmadan daha geniş bir konsept ortaya koyduğu sonucu çıkarlabilir. Meşru savunmanın gereklilik ve orantılılık şartının çok daha sıkılaştırılmasından da meşru savunma konseptinin terk edilmediği sonucuna varlabilir.

Bu çalışmada kolluğun silah kullanmasına ilişkin yeni Fransız çerçeve yasasının kolluğa özgü nasıl bir meşru savunma konsepti ihdas ettiğini Türk hukukundaki durumu da ele alarak değerlendireceğiz.

Anahtar Kelimeler: Silah kullanma yetkisi, önleyici faaliyetler, meşru savunma, kanunun hükmünü yerine getirme, hukuka uygunluk.

\section{Introduction}

Law enforcement forces can use weapons as required by their duties within the framework of maintaining public order and struggling against crime and criminals. The use of weapons should be used as the last resort (ultima ratio) in case other measures do not benefit. The use of weapons directly targets the body integrity of the person and the right to life. For this reason, the use of weapons, which is directed towards the most valuable rights, may 
become legitimate within the concept of legitimate defence or in a concept that means very close to legitimate defence.

When the engagements regarding the circumstances under which the law enforcement forces can use their weapons are examined, it is seen that they can use their weapons for circumstances other than legitimate defence. However, this does not mean that the law enforcement forces can use weapons out of proportionality to the intended purpose in these cases. For example, the killing of the suspect to be arrested will be an unlawful and disproportionate act within the framework of the authority to the use of weapons.

In this study, we will specifically examine the law enforcement forces' authority to the use of weapons in a fatal way. In particular, we will ask the question of whether a weapon can be used in a fatal way, except for the concept of legitimate defence. In doing so, we will compare the situation in Turkish law with the French law, which established a common framework of the use of weapons for all kind of law enforcement forces in 2017. We will discuss whether the authorization to the use of weapons, which was taken up with a new concept in Turkey in 2015 and in France in 2017, constitutes a wider concept than legitimate defence in this sense.

\section{Generally}

After the events in October 2014', article 16 of the Law on Police Duties and Authorities (LPDA) regarding the use of weapons ${ }^{2}$ by the police was amended by the law numbered 6638, which is publicly known as the Internal Security Package. After the attacks in France in January and November $2015^{3}$, the authorization of the internal security forces to use weapons was unified under a single provision and Article L.435-1 of the Internal Security Code $\left(\mathrm{CSI}^{4}\right)$ was created ${ }^{5}$. In France, just after the enactment of the law numbered

Hazal Duran, "5 Soru: 6-8 Ekim Olayları”, https://www.setav.org/5-soru-6-8-ekim-olaylari/ (Online: 20.04.2021)

2 In this study, the term "weapon" refers to the "fire weapons".

3 M. Éric Ciotti, "Rapport fait au nom de la commission des lois constitutionnelles, de la législation et de l'administration générale de la république sur la proposition de loi ( $\left.{ }^{\circ} 3271\right)$ visant à élargir les capacités d'intervention des forces de l'ordre, https://www.assembleenationale.fr/14/rapports/r3446.asp (Online 20.04.2021)

4 According to the abbreviation derived from the French name of the code "Code sécurité intérieure".

5 The legislation process of the provision is examined below, under the title of "Legal Framework". 
2017-258 of February 28, 2017 ${ }^{6}$, which envisages a common framework for using weapon for the different units of the police and the gendarmerie, on May 20,2017, the gendarmerie officials killed a person who fled on the narrow dirt road after two warnings. On May 30, 2017, police officers likewise opened fire on a person who came rapidly in their direction with a vehicle reported to be stolen. On August 19, 2017, national police officers opened fire on a person who refused to obey the command and attempted to escape from his vehicle ${ }^{7}$.

In France, in the period before the adoption of the laws numbered 2016731 and dated June 3, 2016 ${ }^{8}$ and numbered 2017-258 and dated February 28,2017 , provisions on the use of weapons by law enforcement forces were differentiated ${ }^{9}$ by the type of forces who use weapons as in Turkey ${ }^{10}$. While the gendarmerie forces which have the authority to the use of weapons can perform this authority within the conditions stipulated in the former L. 23383 article of the Defence Code $^{11}$, police officers had the authority to the use of weapons in cases of legitimate defence and state of necessity which are regulated in Articles 122-5 and 122-7 of the French Criminal Code (FCC),

6 The law related to Public Security, numbered 2017-258 and dated February 28, 2017, Official Journal no 51, March 1, 2017.

7 About above-mentioned incidents see Catherine Tzutzuiano, "L'usage des armes par les forces de l'ordre", 2017, 4, Revue de Science Criminelle et de Droit Pénal Comparé (RSC), p. 699-700.

8 Law to strengthen the fight against organized crime, terrorism and its financing, and improve the efficiency and guarantees of criminal proceedings, numbered 2016-731 and dated June 3, 2016, Official Journal, no 129, June 4, 2016.

9 Except for the dissolution of gatherings that require the use of force including the use of weapons, which are within the authority of the gendarmerie and the national police. Article 431-3 paragraph 1 of French Criminal Code defines what the gathering (attroupement) means. According to this "Any gathering of people on the public way or in a public place liable to disturb public order constitutes a gathering." For detailed information about the dispersion of gathering in French law, see Mathias Murbach-Vibert, "Attroupement", in Répertoire de droit pénal et de procédure pénale, Dalloz, no 81 et al.

10 Law enforcement forces authority to the use of weapons is regulated in different laws like the Gendarmerie Organization, Duties and Authorities Law and the Coast Guard Command Law such as regulated in the LPDA. Although there are no detailed provisions regarding the authorization to the use of weapons in the mentioned laws, Article 25 of the LPDA and Article 5 of the Coast Guard Command Law have somehow stipulated that the authorization to the use of weapons in the LPDA is also valid for the Gendarmerie and Coast Guard forces and have created a common framework for these units in terms of use of weapons. (Izzet Özgenç, Türk Ceza Hukuku Genel Hükümler, $16^{\text {th }}$ Ed., Seçkin Yayınları, Ankara, 2020, p. 335, ftn. 455.)

11 Gendarmerie can also be deployed to prevent or interrupt any intrusion into a highly sensitive defense area according to art. L. 4123-12-I of Defence Code. 
indistinguishable from ordinary citizens. The legitimization of the use of weapons in a state of necessity ${ }^{12}$, which is seen as justification fact in French criminal law, was one time accepted by the Criminal Chamber of the French Court of Cassation ${ }^{13}$. In contrast, law enforcement forces often use weapons within legitimate defence, in France and Turkey. The police, like everyone else, in using weapons within the scope of legitimate defence, must meet the conditions of legitimate defence. For this, there must be an illegal aggression against himself or someone else, the use of weapons must be a necessity, weapons must be used against an actual attack and the weapons must be used proportional to the aggression ${ }^{14}$. In this sense, it is said that the conditions for legitimate defence of both countries are similar. Although the provisions on the authorization to the use of weapons seem to allow the use of weapons outside of the legitimate defence, is this a use outside the legitimate defence concept or is it a special concept of legitimate defence specified to law enforcement forces? In this study, this problematic will be evaluated by taking the French example into consideration.

12 The state of necessity is not a justification fact which is very compatible with the situations where the police can use weapon. Necessity presupposes the actuality of a danger rather than an aggression. In this respect, the source of danger is non-human, it is a natural event or animal attack or etc. A person who wants to avoid danger in case of state of necessity harms the right of a third person who is not related to the danger. In other words, the third person is victim and innocent. Therefore, the state of necessity is not an institution that will work for the person using a weapon in response to an actual or hypothetical attack. The person in this situation is not in state of necessity but in a legitimate defence if other conditions exist. In legitimate defence, "danger arises from an aggression, and the source of aggression is human. The source of the danger can be identified and the person is considered as an aggressor and has to bear all the harmful consequences of the act of a person who does nothing but respond to his attack." See Corrine Mascala, "Faits justificatifs - Etat de nécessité", in J.-Cl. Pénal Code, LexisNexis, 2016, no 20.

13 French Court of Cassation Criminal Section (hereinafter Crim.) 16.07.1986, Recueil Dalloz (hereinafter D) 1988, p. 390.

14 On the conditions of legitimate defence in Turkish criminal law see, Özgenç, p. 367 et al; M. Emin Artuk/Ahmet Gökcen/M. Emin Alşahin/Kerim Çakır, Ceza Hukuku Genel Hükümler, $14^{\text {th }}$ Ed., Adalet, Ankara, 2020, p. 506 et al; Zeki Hafızoğulları/Muharrem Özen, Türk Ceza Hukuku, Genel Hükümler, 12th Ed., Seçkin, Ankara, 2019, p. 220-221; Mahmut Koca/İlhan Üzülmez, Türk Ceza Hukuku Genel Hükümler, 13th Ed., Seçkin, Ankara, 2020, p. 284-285; On the conditions of legitimate defence in French criminal law see, Jean Pradel, Droit pénal general, $21^{\text {st }}$ Ed., Cujas, Paris, 2016, p. 320 et al; Bernard Bouloc, Droit penal general, $25^{\text {th }}$ Ed., Dalloz, Paris, 2017, 367 et al; Emmanuel Dreyer, Droit pénal general, $4^{\text {th }}$ Ed., LexisNexis, Paris, 2016, p. 903 et al; Michèle-Laure Rassat, Droit pénal général, 4th Ed., Ellipses, 2017, Paris, p. 396-397. 


\section{Legal Framework}

The terrorist attacks that took place in Paris in January and November 2015, the attacks against soldiers ${ }^{15}$ and policemen ${ }^{16}$ in different parts of France, especially the attacks in the autumn of $2016^{17}$ targeting the police, caused to reopen the arguments on authority to the use of weapons by law enforcement forces especially the national police. Considering that the conditions of legitimate defence are insufficient to prevent these attacks and independently from that insufficient to fulfil the security obligation of the police, the French Government has taken steps to redefine the framework of using weapons. The draft law on public security, which particularly touches the works ${ }^{18}$ of the mission on the framework of the law enforcement forces authority to the use of weapons under the presidency of Hélène Cazaux-Charles, was submitted to the French National Assembly on December 21, 2016. It was also legislated on February 28, 2017 as the Law No. 2017-258 related to Public Security.

This law adds Article L. 435-1 to the CSI, establishing a common framework of authorization to the use of weapons for all internal security forces. The law has brought together ${ }^{19}$ the rules on the use of weapons as a

15 In the city of Nice on February 3, 2015, two soldiers were wounded in a knife attack by an aggressor. In the city of Valence, on January 1, 2016, an aggressor attempted to hit four soldiers on patrol with his vehicle. About above-mentioned incidents see Tzutzuiano, p. 701.

16 In December 2014, an aggressor was shot to death after attacking three police officers with a knife. In January 2015, the aggressor, armed with a knife and a fake explosive device, was killed while attempting to attack four police officers on duty. On January 7, 2015, two police officers were killed by two brothers during the Charlie Hebdo attack in Paris. A police officer was also killed in Montrouge in the same day. On June 13, 2016, a police officer and an officer of the Ministry of the Interior were killed with an assault knife. A police officer was killed with a machine gun on the Champs-Élysées just after the new framework on the law enforcement forces' authority to the use of weapons came into force. About abovementioned incidents see Tzutzuiano, p. 701.

17 On October 8, 2016, four police officers in their vehicles were attacked with a Molotov cocktail. After this attack, in which two of the four police officers were injured with severe burns, the police started to protest the insufficiency of the law. (Tzutzuiano, p. 701.)

18 November 2016 Mission Report on the Framework of the Legal Authority of the Security Forces to the Use of Weapons, chaired by Hélène Cazaux-Charles, Director of the National Institute for Justice and Security High Studies. (Institut national des hautes études de la sécurité et de la justice, "Le cadre legal de l'usage des armes par les forces de sécurités", Rapport of Mission chaired by Hélène Cazaux-Charles, 2017, no 39, Cahiers de la sécurité et de la justice, p. 39 et. al.)

19 In the same vein Tzutzuiano, p. 701. 
framework law ${ }^{20}$, which can be applied to the national police and gendarmerie, to date, specifically regarding the gendarmerie. In this way, law enforcement forces can use their weapons in response in five situations within the framework of a common regime. Situations in which law enforcement forces can use weapons are called engagements. The first four engagements are to reconsider and make more pronounced the authority to the use of weapons, previously stipulated for the gendarmerie in Article L. 2338-3 of the Defence Code. The fifth engagement is the fact that the provision legislated as Article 122-4-121 of the FCC with the law dated June 3, 2016 and numbered 2016-731 was taken into the CSI one year after its enactment.

In Turkey, after the events of October 2014, Law No. 6638, publicly known as the Internal Security Package, made a change in the regime of the police authority to the use of weapons with a similar reactance. The law added clause (d) as a new engagement to paragraph 7 of article 16 of the LPDA.

After the amendment, the provision of article 16/7 of LPDA, which regulates the substantial engagements regarding the use of weapons by police is as follows:

"The police are authorized to the use of weapons;

a) within the scope of the right to legitimate defence,

b) with the aim of to break the resistance proportionally, in case of

20 The law concerns national police, national gendarmerie forces, forces deployed in the country under the Operation Sentinelle and customs guards. In accordance with Article L. 2338-3 of the Defence Code, military forces responsible for the protection of military facilities may also use weapons in this context, except for the engagement regulated in the fifth paragraph. Whether these provisions are applicable to the municipal police or not has been discussed at length in the Parliament. The Senate wished to extend the engagements in the first and fifth paragraphs of Article L. 435-1 to the municipal police as well. However, the National Assembly partially removed this extension from the law. The Joint Commission decided that only the engagement in the first paragraph, which actually defines the legitimate defence, was also applicable to the municipal police. (Internal Security Code, Art. L. 511-51). Finally, it should be said that, in accordance with Article 12 of the law numbered 20091436 and dated 24 November 2009, forces in prison can use weapon within the scope of the engagements in the first and second paragraphs of the common framework.

${ }^{21}$ Article 122-4-1 of the French Criminal Code was amended to the Code with the law numbered 2016-731 and dated June 3, 2016, in connection with the justification fact order of the law under the title of the reasons that cause irresponsibility or attenuation of the responsibility. Today, this provision has almost the same text and is included in the 5th paragraph of the L. 435-1 article of the Internal Security Code. (Jean Pradel, "Pour une légitime défense spécifique aux membres des forces de l'ordre", 2016, D, p.2525) 
resistance that s/he cannot neutralize by using physical force and material power,

c) with the aim of ensuring proportionally to arrest of persons for whom a warrant of detention, custody, to cow or arrestment has been issued or arrest of red-handed suspect,

d) with the aim of to make proportionally the aggression ineffective, against those who attack or attempt to attack with molotov, explosive, flammable, incendiary, choking, wounding and similar weapons to themselves or others, workplaces, residences, public buildings, schools, dormitories, places of worship, vehicles and open or closed areas where persons are individually or collectively."

Following the change in the use of weapons regime of the law enforcement forces in France, article L. 435-1 of the Internal Security Code is as follows.

"In the exercise of their functions and wearing their uniform or external and visible insignia of their quality, in addition to the cases mentioned in article L. 211-9, the agents of the national police force and the soldiers of the national gendarmerie can use their weapons within absolute necessity and strictly proportionality:

1) In case of attacks on life or physical integrity are brought against them or against others or when armed persons threaten their life or their physical integrity or those of others;

2) When, after two summons made aloud, they cannot otherwise defend the places they occupy or the people entrusted to them;

3) When, immediately after two summons aloud, they cannot compel to stop, other than by the use of weapons, persons who seek to escape their custody or their investigations and who are likely to perpetrate, in their flight, attacks on their life or their physical integrity or those of others;

4) When they cannot immobilize, other than by the use of weapons, vehicles, boats or other means of transport, whose drivers do not comply with the stop order and whose occupants are likely to perpetrate, in their flight, attacks on their life or their physical integrity or those of others;

5) With the exclusive aim of preventing the repetition, in an approaching time, of one or more murders or attempted murders which have just been committed, when they have real and objective reasons to consider that this 
repetition is probable in view of information they dispose when they use their weapon."

As it can be understood from the text of the French provision, in legally prescribed circumstances and under the conditions specified by this article, internal security forces are authorized to the use of weapons while performing their duties and wearing their uniforms or external symbols and their qualities are understandable ${ }^{22}$. On the other hand, the Turkish provision does not require the quality of the law enforcement forces can be understandable (with a symbol visible on the uniform or clothing) as a condition to the use of weapons. The most distinctive difference between the two provisions is that the French provision's engagements are stipulated as close to legitimate defence as much as possible ${ }^{23}$.

Although they do not refer to this in the texts of the two laws ${ }^{24}$, the use of weapons also embodies the (justification fact) authorization of the $1 \mathrm{aw}^{25}$ within the scope of article 24/1 of the Turkish Criminal Code (TCC) and article 122-4

22 Internal Security Code Article L. 435-1 does not apply when law enforcement forces keep weapon out of duty and are in a legitimate defence. Tzutzuiano, p. 702.

23 In comparative law authority to the use of weapons by law enforcement forces are stipulated in a very close manner with legitimate defence concept. According to Spanish law of March 13, 1986 on police's authority to the use of weapons "a weapon can only be used in situations in which there is a serious risk of harm to the physical integrity of a person or a serious risk of harm to public security ". German federal law of March 10, 1961 on the use of firearms: according to its article 10, federal police officers "may only use their weapons in order to prevent the imminent commission of a crime or misdemeanour when the latter involves the use or carrying of a weapon or explosive ". The Belgian law of August 5, 1992 on the police function provides that "police officers may only use firearms (...) if it is reasonably possible to suppose that people have a weapon ready-made fire and that they would use it against people." For the provisions in comparative law related to using weapon by police see, Jean Pradel, Droit pénal comparé, 4th Edition, Dalloz, 2016, no 102 et al.

24 Provisions regarding the law enforcement forces authority to the use of weapons regulate armed behaviours that are lawfull due to other reasons in the form of engagements so that law enforcement officers do not hesitate. (In the same vein M. Bedri Eryılmaz/Ayhan Bozlak, "Hukukumuzda Zor Ve Silah Kullanma Yetkisi", 2009, 83, TBB Dergisi, p. 237, 247.) According to Décima, the provisions of the law enforcement forces' use of weapon are intriguing provisions by their aims. Because these provisions generally aim to legitimize the usual activity (modus operandi) of the law enforcement forces. In other words, there is a determination to provide a legal guarantee that no crime can be committed with the police's weapon in his usual activities. Bkz. Olivier Décima, "Terreur et métamorphose - À propos de la loi no 2016-731 du 3 juin 2016 sur la lutte contre le terrorisme", 2016, D., p. 182.

25 Özgenç, p. 332 et al.; Hafizoğulları/Özen, p. 213; Koca/Üzülmez, p. 276-277, ftn. 770; Artuk/Gökcen/Alşahin/Çakır, p. 484. 
of the $\mathrm{FCC}^{26}$. This justification fact which is frequently mentioned fact in both countries regarding the use of weapons by the police or the duty performed by the police. This fact is the justification fact which is applied generally within the scope of irresponsibility of the police when use of weapons. However, the Turkish provision also bases the TCC's provision on legitimate defence in its text ${ }^{27}$. When the use of weapons by the law enforcement forces is linked to the authorization of the law, a wider domain of justification appears compared to legitimate defence. When two countries' provisions are read, it can be said that this is the purpose of the legislators at first sight ${ }^{28}$.

Then the following question must be asked. After the changes in terms of law enforcement forces' use of weapons, do the legislators present a wider framework other than legitimate defence? In other words, is this framework a justification that is really separate from the justification of legitimate defence?

When the framework of the authorization of the law is put to the fore, the legislator of course wants to adapt the use of weapons to the public security duty of the police ${ }^{29}$, different from ordinary citizens. Considering the constitutional ${ }^{30}$ and supranational provisions ${ }^{31}$ regarding the use of weapons,

26 Pradel, Droit pénal general, p. 307; Rassat, p. 385 et al.; Bouloc, p. 357; Dreyer, p. 887 et al.

27 "In cases where legitimate defence is in question, it is necessary to make an assessment directly based on the provisions of the TCC on legitimate defense, without applying to the provisions of the legislation regulating the use of force and weapons by the police." Eryilmaz/Bozlak, p. 244.

28 Ibid, p. 245 et al.

29 Yves Mayaud, "Violences mortelles par un gendarme, ou d'une justification de transition", 2018, RSC, p. 87.

30 Paragraph 4 of Article 17 of the Turkish Constitution states that reasons other than legitimate defence may legitimize the use of weapons. According to the article "The act of killing in case of self-defence and, when permitted by law as a compelling measure to use a weapon, during the execution of warrants of capture and arrest, the prevention of the escape of lawfully arrested or convicted persons, the quelling of riot or insurrection, or carrying out the orders of authorized bodies during state of emergency, do not fall within the scope of the provision of the first paragraph." (For English translation of the Constitution of the Republic of Turkey see https://www.anayasa.gov.tr/en/legislation/turkish-constiution/ (Online 05.02.2021)

31 Paragraph 2 of the article 2 of European Convention on Human Rights states that reasons other than legitimate defence may legitimize the use of weapons. According to the article "Deprivation of life shall not be regarded as inflicted in contravention of this Article when it results from the use of force which is no more than absolutely necessary: (a) in defence of any person from unlawful violence; (b) in order to effect a lawful arrest or to prevent the escape of a person lawfully detained; (c) in action lawfully taken for the purpose of quelling 
this framework can be considered to be separate from the concept of legitimate defence. However, when the conditions required by the specific domestic provisions to the use of weapons and each engagement are examined, there is not an obvious distinction. Thus, the use of weapons gets closer to the concept of legitimate defence ${ }^{32}$.

\section{The separation of the regime of the use of weapons from legitimate defence}

While establishing a specific authority to the use of weapons for law enforcement forces, the legislator acts with the aim of adapting this authority to the security situations that law enforcement forces may face. It should be noted that law enforcement forces are usually performing preventive duties. One of the main duties of the law enforcement forces is to take measures to prevent the deterioration of public order $^{33}$. In adapting the use of weapons to law enforcement forces, different from ordinary citizens, it is necessary to stretch the actuality condition which is one of the conditions of legitimate defence. For this reason, the legislator makes it legally possible to engage the use of weapons before aggression in a preventive nature.

\section{A. Stretching the condition of the actuality of an aggression}

The provisions on the authority of the law enforcement forces to the use of weapons are differing from legitimate defence in terms of not seeking the actuality of an aggression, which is a material condition of legitimate defence. According to the Article 122-5 of the FCC, the act of defence must be realized simultaneously (“... dans le même temps...") with the act of aggression. Turkish law expresses a wider provision than the French one in terms of the actuality condition. Accordingly, the aggression must be an aggression that is occurring or is certain to occur or repeat ${ }^{34}$. The simultaneity in the French

a riot or insurrection."

32 Tzutzuiano, p. 703.

33 Jacques Buisson, L'acte de police, volume II, Lyon, 1988, p. 531 et al.

34 According to the justification of the art. 25 of Turkish Criminal Code "...in terms of the "unlawful aggression" condition of the legitimate defence, "unlawful aggression that occurs" and "unlawful aggression that will occur in certainty" or "unlawful aggression that will repeat in certainty" are deemed the same. Thus, the ability of individuals to protect themselves against unlawful aggressions is further expanded." In our opinion, what is mentioned is not about the unlawfulness feature of the aggression, but it is about the actuality of the aggression. 
provision can also be read in this manner ${ }^{35}$. On the other hand, the requirement of simultaneity regarding the use of weapons is not stipulated in Article L 4351 of CSI.

The first engagement in French provision, which gives the authority to the use of weapons, takes into account the aggression against life or body integrity of themselves or another person, or the threat of armed person to the life or body integrity of themselves or someone else. This situation, which allows the law enforcement forces to use of weapons, is close to legitimate defence. But, unlike legitimate defence, the actuality or simultaneity of the aggression is not stipulated in first situation. In terms of the LPDA provisions, article 16/7 (b) and (c) clauses that allow the use of weapons do not mention the actuality of an aggression too.

The same applies to the other three following situations stipulated in Article L. 435-1 of CSI. No condition regarding the actuality of an aggression is legally stipulated. The actuality of an aggression or, more broadly, the absence of the simultaneity condition of defence has been the subject of discussions in the legislation process of this provision in France. These discussions focused specifically on the third situation of the use of weapons after two warnings to fugitives who were suspected of attacking the life or body integrity of law enforcement forces or others during their flight, and the fourth situation of the use of weapons to the driver of transportation vehicles not obeying the stop instructions after two warnings. Within the framework of these discussions, a time indicator was first included in the draft provision. Accordingly, the threat of attack against life or body integrity in these two situations of the use of weapons should have been "imminent" ${ }^{36}$. Considering the condition of the actuality of an aggression in the legitimate defence, the formulation of this time indicator made it difficult to point out even a slight difference. Indeed, according to the law, in legitimate defence, the act of defence must be realized

35 On how the condition of actuality in legitimate defence is evaluated in French criminal law, see. Roger Bernardini, "Légitime defense", in Répertoire de droit pénal et de procédure pénale, Dalloz, no. 50-66.

36 The third and fourth paragraphs of Article L. 435-1 were worded as follows: "3- When, immediately after two summons addressed aloud to persons seeking to escape their custody or their investigations, they can compel these persons to stop only by use of their weapons, in order to prevent them to perpetrate imminent attacks on their or third parties' life or body integrity. 4- When they cannot immobilize vehicles, boats or other means of transport, whose drivers do not comply with the stop order, other than by use of their weapons, in order to prevent them from committing imminent aggression to their or third parties' life or body integrity." 
simultaneously. Considering the case-law regarding the application of this justification fact, the fact that the attack was imminent other than present, justifies the legitimate defence equally ${ }^{37}$. Time indicator of the original draft is annulled to give authorization to the use of weapons against persons suspected of attacking themselves or someone else's life or body integrity during their flight, without any other time requirement only with a prior warning or a stop order. In this way, the legislator wanted to clearly state the distinction between the justification facts authorization of the law and the legitimate defence. With the same considerations, the draft text has widened compared to the legitimate defence in terms of "the scope of situations specifically authorizing the use of weapons ${ }^{38}$ ".

Only the fifth situation stipulated by article L. 435-1 contains a time indicator. In this situation, the authorization of the law enforcement forces to the use of weapons is stipulated in order to prevent the repetition of one or more murder or attempts to murder in the "approaching time". It is necessary to mention this condition as a condition of actuality and in this case, this condition should be considered as a condition of justification. However, we cannot refer to this condition as a condition similar to the actuality condition in the legitimate defence. Anyway, the fifth engagement has deliberately preferred the broader term "approaching time" rather than the "imminent time". The question to be asked here is: what is meant by the approaching time? Does it represent a relatively short period of time, or should it be understood as a time spreading to days? For example, if there is a suspicion that the perpetrator of just committed one or more murder or attempted murder will repeat, in how long time should he be neutralized? In addition, determining the time scope of the expression "just" is a separate problem.

On the other hand, the legislator seems to have granted an authority for the act of repression, by stipulating the condition that the use of weapons should be used in the approaching time following one or more murder or attempts to murder. But it is not so. For the use of weapons after one or more murder or attempts to murder, law enforcement forces should be convinced that repetition of these acts is probably ${ }^{39}$. This situation makes it legitimate

37 See, Tzutzuiano, p. 709 et al.

$38 \mathrm{CNCDH}$, Opinion on the Law related to public security, February 23, 2017, p. 10. https:// www.cncdh.fr/sites/default/files/170223_avis_sur_le_projet_de_loi_securite_publique_1. pdf (Online 06.02.2021)

39 "...the condition of a "probable" reiteration introduces a dose of subjectivity that is difficult 
to realize a defensive action before an aggression, which is also valid for the previous four engagements. Thus, the legislator legally stipulates the legitimacy of a preventive defence action.

In terms of LPDA, clause (d) of article 16/7 implies a similar provision. Accordingly, law enforcement forces can use weapons against persons who have attacked or attempted to attack with certain materials. The text of the clause (d) seems to authorize to the use of weapons against an aggression that is finished and not actual. However, the text subjects the use of weapons to the aim of making the aggression ineffective and the criteria of proportionality that would make it ineffective ${ }^{40}$. By the way it is necessary to conclude that the aggression will be repeated. But there is no determination as in how long time it will be repeated. At this point, it is necessary to look at the condition of actuality in the legitimate defence concept. Moreover, since the provision does not make an extension (imminent time - approaching time) unlike the French one, the actuality must be understood as an aggression will repeat in certainty ${ }^{41}$.

The engagements in LPDA Art. 16/7-(b) and (c) authorize to use of weapons outside the legitimate defence. In Turkish doctrine, there is no author examining these provisions within the concept of legitimate defence. This situation is the result of considering the use of weapons within the concept of authorization of the law and outside of legitimate defence. In both clauses, there is not the slightest indication to remind legitimate defence. In particular, the engagement in clause (b) has been written by the legislator without considering any concept. Because this engagement is already a prerequisite for using weapon ${ }^{42}$. In the concept of the authorization of the law, the assessment

to assess. In short, it is to be feared that we will replace one legal uncertainty with another. On the other hand, why we limit the right of the police to the pre-existence of a murder or an attempted murder?" Pradel, "Pour une légitime défense spécifique aux membres des forces de l'ordre", p.2525.

40 For the criticism saying that the authorities stipulated in the clause are already in the scope of legitimate defence and unnecessary, see, Koca/Üzülmez, p. 277, ftn. 770; Adem Sözüer, Türk Ceza Hukuku Mevzuatı, Alfa Yayınları, $4^{\text {th }}$ Ed., İstanbul, 2015, p. 15-17; On October 8, 2016, four police officers in their vehicles were attacked with a Molotov cocktail. After this attack, in which two of the four police officers were injured with severe burns, the police started to protest the insufficiency of the law. About legislating the engagement of the use of weapons corresponding to molotov cocktail attacks, process in France and Turkey are similar.

${ }^{41}$ In the same vein, Sözüer, p. 15-17

42 Ery1lmaz/Bozlak, p. $245-246$. 
of the proportionality between interests is quite different from the legitimate defence. First of all, in authorization of the law, it is stated by the law that the interest to be obtained by the fulfilment of a duty whose conditions have been met, is superior to the interest which is harmed and this is a presumption. Acknowledging a behaviour as lawful requires existence of a balance or at least equivalence between the interest sought to protect and the interest which is harmed. It is accepted that the legal interest protected by the authorization of the law is more valuable than whatever harmed interest is related to the subject ${ }^{43}$. As such, law enforcement forces may use weapon targeting the person's body even when engagements other than legitimate defence are in question. Since it is assumed that the expected interest from the authorization of the law outweighs, the act will be lawful and legitimate. In this sense, it is accepted that the interest to be obtained by the person's arrest is superior to the harmed interest to be caused by his injury ${ }^{44}$.

In France, before the common framework came into force, the police could only use of weapons in legitimate defence. Within the authority arising from Article 73 of the Code of Criminal Procedure, law enforcement forces can arrest red-handed like anyone else. During that period, in some cases, law enforcement forces used their weapons for arrest (when there was no legitimate defence) and claim that they could use of weapons in such situation within the framework of the concept of authorization of the law. Although the French Court of Cassation stated that the police could use of weapons in these cases, it also evaluated the proportionality by not accepting that the interest to be obtained by authorization of the law is automatically superior to the harmed interest. ${ }^{45}$.

43 Zeynel T. Kangal, "Ceza Hukukunda Hukuka Uygunluk Nedeni Olarak Kanun Hükmünün Yerine Getirilmesi”, 2012, 89-90, Bahçeşehir Üniversitesi Hukuk Fakültesi Kazanc1 Hakemli Hukuk Dergisi, p. 27-28.

44 Ibıd. The author defines it as "predominating value" (ăgır basan yarar); In the same vein Koca/Üzülmez, p. 277, ftn. 770; “...This is because the conditions of application of article 174 of the decree of May 20, 1903 were met, which confer the ability to the use of weapons to immobilize vehicles not complying with a stop order. However, since there was authorization of the law, the action carried out entailed criminal irresponsibility, even for an involuntary fault committed during the execution of the prescribed act. The solution can only be approved, because the authorization of the law, unlike legitimate defence, is unqualified. If it exists, it validates the action taken." (Bernard Bouloc, "Autorisation de la loi. Admission. Portée", 2000, RSC, p. 817)

45 See, Crim. 13.04.2005, $\mathrm{n}^{\circ}$ 04-83.939, Criminal Bulletin, $\mathrm{n}^{\circ} 131$. 


\section{B. Allowing the preventive actions of law enforcement forces}

By not seeking the actuality of an aggression, which is a material condition of legitimate defence, the French provision established a framework for the use of weapons by law enforcement forces on the basis of preventive action $^{46}$. Examination of the provision of Article L. 435-1 reveals that indeed the law enforcement forces can use their weapons against a person suspected who going to attack his or another person's life or body integrity to prevent the occurrence of these consequences. In other words, it is the preventive legal authority given to law enforcement forces in five situations that they may face.

By the acceptance of the legitimacy of the defence action before the act of aggression, the legislator recognizes the authority to the use of weapons only if the law enforcement forces are faced with the "suspected" or "probable" act of aggression against life or body integrity (hence it is also difficult to call this act a defensive behaviour). The absence of actuality condition is therefore related to the assessment of the reality of the attack. For this reason, law enforcement forces will have to evaluate the suspicion that an aggression will realize in order to decide whether there is or not the authority to the use of weapons in the heat of the circumstances. In this way, the legislator puts law enforcement forces in a sensitive position that will be the source of very serious discussions. Because evaluating the probability of an aggression is up to the law enforcement forces. Probability is a considerable wider margin than certainty. This situation will rightly raise many controversies for no reason ${ }^{47}$.

For example, in application of the third situation stipulated by Article L. 435-1 of CSI, especially in close follow-ups in the city, what is the probability degree of the suspicion that the person using the vehicle of transport, who is running away, will attack the life or body integrity of the law enforcement forces or someone else? Or, in the application of the fifth situation stipulated by the same article, depending on the time indicator in the text of the article, how can the law enforcement forces know that the action suspected to realize is a

46 "...But legitimate defence here suffers from a double handicap. First, it places the police under the same regime as any individual while they are in a different material position, as has just been said. Then, the conditions of legitimate defence are strictly understood and, more precisely, those of the current nature of the aggression, the need for defence and a proportion between the seriousness of the threat and the intensity of the response." Pradel, "Pour une légitime défense spécifique aux membres des forces de l'ordre", p.2525

47 Similar approaches took place in the $\mathrm{CNCDH}$ opinion on the law related to he public security (February 23, 2017) and the oppinion of Défenseur des droits (January 24, 2017) https:// juridique.defenseurdesdroits.fr/doc_num.php?explnum_id=18573 (Online 06.02.2021) 
repetition of the act of murder or attempting to murder? Here, law enforcement forces have been given a considerable wide margin of appreciation. This deprives law enforcement forces of the legal certainty ${ }^{48}$ they need in this field, and as in the examples we gave under the title (I), these provisions were applied after the article legislated and will be applied frequently. Undoubtedly, in the case of legitimate defence, the evaluation of the actuality and reality of the aggression is up to the law enforcement forces. However, the age-old practice of legitimate defence and the stability of the case law in this field mean a legal certainty that narrows the margin of appreciation of law enforcement forces.

Indeed, in some cases it can be quite difficult to detect the existence of these conditions. These are the situations in which the police officer has difficulty in assessing the extent of the aggression ${ }^{49}$ against him, or when it becomes difficult to assess whether the person is dangerous from his physical movements ${ }^{50}$, for example preparing to pull a knife or a gun. However, the determination of the actuality and the of the act of aggression is the subject of established case law. This know-how provided by the established case-law also provides a number of legal certainty, which the new provision on the use of weapons by the law enforcement forces does not envisage them.

The advantages of the aforementioned article L. 435-1 of CSI to law enforcement forces depend on how the judicial authorities will handle this probability aspect of the actual aggression. If the judicial authorities take

48 The justification of the Law related to the Public Security defines the new framework of the authority to the use of weapons as "...obvious, previsible and adapted to the threats that people who maintain public order may face while performing their duties." ECtHR jurisprudence state that those who maintain public authority and order should have a legal framework that sets specific instructions and criteria for the use of force. (See, ECtHR, GC., 20.12.2004, Makaratzis v. Grèce, no 50385/99; Jean-François Flauss, "Actualité de la Convention européenne des droits de 1'homme" (août 2004 - janv. 2005), 2005, Actualité juridique droit administratif (AJDA), p. 541). $\mathrm{CNDH}$, in its opinion given above, "even the definition of the engagements regarding the authority of law enforcement forces to use of lethal weapons in a single article reveals the inadequacy by itself... Such an approach can provide legal assurance surrounding law enforcement forces if only the text is written to reflect the rule of law." In this context, while examining the text of the law of June 3 , 2016, the French Council of State emphasized that a very wide margin of appreciation is likely to deprive law enforcement forces of the legal certainty they need. (See, Conseil d'Etat, Interior and Finance Sections, Opinion on the project of law strengthening the struggle against organized crime and its financing, the efficiency and guarantees of criminal proceedings, no 391004, 28.01.2016).

49 Olivier Décima, “Légitime réforme?", 2016, D., p. 2527; Paris Court of Appeal, 9.10.1978, 1979, II, JCP p. 19232, note Pierre Bouzat.

50 Lyon Court of Appeal, 16.12.1986, 1987, 1, Gazette du Palais, p. 199. 
lower the level of probability, scope of action of the law enforcement forces to the use of weapons will emerge wider than the area provided by legitimate defence. To put it on the contrary, if the judicial authorities handle this level of probability higher, the scope of action of the law enforcement forces to the use of weapons will more coincide and resemble the context of legitimate defence ${ }^{51}$.

It is difficult to determine with certainty what the level of probability is sought as a condition in the article, as the case law has not yet set a standard under the article L. 435-1 of the CSI. Nevertheless, by subjecting these five situations that allow the use of weapons to the common conditions of "absolute necessity" and "strictly proportionality", the legislator imposes the existence of the really approaching act of aggression ${ }^{52}$. These common conditions required by the legislator are also the framework of the justification fact legitimate defence.

The Turkish provision does not regulate the necessity and proportionality as a common condition for all engagements regarding the use of weapons, except where it refers to legitimate defence. Moreover, the French provision, which stretches the condition of actuality in terms of authorization to the use of weapons compared to the concept of legitimate defence, on the other hand strengthens the necessity and proportionality conditions of legitimate defence. In this sense, it regulates the condition of necessity as "absolute necessity" and the condition of proportionality as "strictly proportionate" 53 .

\section{Mistake in concept of legitimate defence-Condition of lawfulness in concept of authorization of the law.}

In addition to stretching the condition of actuality in the context of the law enforcement forces authority to the use of weapons, it is also a matter of law enforcement forces assume an aggression actual that does not actual in reality. As mentioned above, law enforcement forces carry out preventive

51 Tzutzuiano, p. 706.

52 Serge Rayne, "Gendarmerie", in Répertoire de droit pénal et de procédure pénale, Dalloz, no. 167.

53 Gilles Janel, "La nouvelle loi n²017-258 du 28 février 2017 relative à la sécurité intérieure publique a créé un article L.435-1 du Code de la sécurité intérieure définissant un nouveau cadre légal d'usage des armes", 2019, Centre National de la Fonction Publique Territoriale (CNFPT), no: 4. https://www.wikiterritorial.cnfpt.fr/xwiki/bin/view/vitrine/ (Online: $05.02 .2021)$ 
activities. Acting on the suspicion of an aggression that does not actual in reality, the responsibility of the law enforcement forces differs in the concept of legitimate defence and the concept of the authorization of the law. In addition, the provisions of the two countries reach different conclusions about the responsibility of the police in this situation.

Fifth clause of the article L. 435-1 of CSI states that, in view of reasonable information, the fact that the law enforcement forces think an aggression will occur in probability, is a condition of lawfulness. "...when they have real and objective reasons to consider that this repetition is probable in view of information they dispose." However, although such an aggression will never occur, the fact that the police have reason to think this way, raises the issue of mistake. Normally in this case, the police are not in a lawful position and the conditions of lawfulness are not met. According to the French doctrine of criminal law, the one in this situation is in a material mistake and does not act intentionally ${ }^{54}$. However, considering the fifth clause, since even this state of mistake is stipulated as a condition of using weapons, law enforcement force will be in a lawful position and its act will be lawful even if such an aggression will not occur ${ }^{55}$. This fact is related to the concept of the authorization of the law to the advantage of law enforcement forces. In terms of legitimate defence, thinking in view of reasonable information that the aggression will occur which will never occur in reality, cannot be regarded as a condition of lawfulness. In this case, the law enforcement forces will have a negligent responsibility in terms of killing or wounding $\operatorname{acts}^{56}$.

Although the Turkish law has different provisions so that the law enforcement forces do not hesitate to use weapon ${ }^{57}$ in legitimate defence, it does not accept the lawful use of weapons with the thought in view of reasonable information that an aggression will occur which will never occur

54 Dominique Viriot-Barrial, "Erreur sur le droit", in Répertoire de droit pénal et de procédure pénale, Dalloz, no 18; Gildas Barbier, "Art. 122-3: Erreur sur le droit”, in J.-Cl. Pénal Code, LexisNexis, 2015, no 19.

55 Décima, "Légitime réforme?", p. 2527; Pradel, "Pour une légitime défense spécifique aux membres des forces de l'ordre", p. 2525.

56 Barbier, no 21.

57 "... in order to eliminate the hesitations of the law enforcement forces regarding the use of force, this issue has been included in almost all relevant provisions." Eryllmaz/Bozlak, p. 237. 
in reality ${ }^{58}$. Within the framework of Turkish provisions, the police cannot act as determined or confident as their French colleagues in the face of an aggression which will almost surely occur. He must be absolutely sure. The police are in state of mistake if use weapon with the thought that an aggression will occur which will never occur. In this case, the responsibility of the police is evaluated in different ways by Turkish doctrine ${ }^{59}$. According to one view, the person who falls into mistake in the material conditions of the justification facts will benefit from his or her mistake if this mistake is inevitable. If the error is evitable, he or she remains responsible. According to another view, in case of a mistake in the material conditions of the justification facts, the provisions regarding the mistake in the material elements of the crime are applied and the intention is removed ${ }^{60}$. Yet another view claims that, if the mistake of the law enforcement force is an inevitable mistake, it will benefit from this mistake, if it is an evitable mistake, the provisions regarding the mistake in the material elements of the crime are applied by comparison ${ }^{61}$.

As a result, it should be said that if the police assumes that an aggression will occur within the framework of the circumstances it is in, its act is lawful under the fifth clause of the article L. 435-1. Even that aggression would never occur. This supports the argument of a legitimate defence concept specific to law enforcement forces. Considering that this provision was previously stipulated in Article 122-4-1 in connection with the authorization of the law stipulated in Article 122-4 of the FCC, it is said that this special form of legitimate defence including the mistake of police is lawful on the basis of authorization of the law. Turkish law does not have an extending provision covers the mistake of the law enforcement forces in the provisions related to either authorization of the law or legitimate defence. The issue must be evaluated and resolved within the framework of the provisions related to the mistake.

58 Turkish Military Court of Cassation has a decision in opposite way. "By thinking that he was a terrorist, the offender who shot and killed the deceased who came to the emplacement from an improper place by not complying the stop order, did not exceed his authority to the use of weapons." (Turkish Military Court of Cassation, 4th Section, 26.09.1995, 1995/586 E., 1995/605 K.)

59 For detailed research on the mistake in material conditions of justification facts see, Neslihan Göktürk, "Hukuka Uygunluk Nedenlerinin Maddi Koşullarında Yanılgının Hukuki Niteliği”, 2014, 26, Ceza Hukuku Dergisi, p. 7-30.

60 Koca/Üzülmez, p. 302.

${ }_{61}$ Kangal, p. 52-53. 


\section{The proximity of the use of weapons regime to legitimate defence}

Considering the provision of the LPDA in conjunction with Article $17 / 4$ of the Constitution of Turkish Republic, the use of weapons by the law enforcement forces is not subject to the condition of the actuality of an aggression against people's body integrity or life, except for clauses (a) and (d) ${ }^{62}$. Moreover, it cannot be concluded from the provision of clauses (b) and (c) that the use of weapons in such situations is subject to the conditions of legitimate defence. Although the French provision seems at first sight to establish the use of weapons based on the five engagements on a preventive manner in the concept of authorization of the law, different from the legitimate defence, these five engagements are subject to common conditions that are very close to legitimate defence. Indeed, the legislator subjected the use of weapons to conditions of necessity and proportionality, on which case-law is very rigorous in matters of legitimate defence ${ }^{63}$. However, the obligation to meet these conditions raises an unnecessary debate such as leaving the justification fact authorization of the law aimless and comparing it with legitimate defence. In the light of these conditions, the justification fact authorization of the law becomes meaningless and the authority to the use of weapons is included in the field of legitimate defence. Indeed, as we have discussed in this study, it is not clear whether these five engagements on the use of weapons by law enforcement forces are within the scope of authorization of the law or legitimate defence. It cannot be said with certainty that these five engagements differ from legitimate defence. It is argued that these are included in legitimate defence and that the concept of legitimate defence is broader than the criminal law provisions with a flexibility that can be used by the police.

\section{A. The use of weapons by law enforcement forces under absolute necessity and strictly proportionality}

Article 16/7 of the LPDA regulates the use of weapons as a priori, beyond legitimate defence, in the concept of authorization of the law. Case law especially restricts the scope of engagements stipulated in clauses (b)

62 Some engagements about the law enforcement forces authority to the use of weapons are nothing more than legitimate defence. The legislator has regulated these engagements in order the law enforcement forces not to hesitate while performing his duty. In the same vein, Eryılmaz/Bozlak, p. 247.

63 Jacques Buisson, “Nécessité et proportionnalité dans l'usage de l'arme à feu”, 2006, RSC, p. 419. 
and (c) ${ }^{64}$. In accordance with the first paragraph of Article L. 435-1 of the CSI, law enforcement forces use weapons only under "absolute necessity and strictly proportionate". The legislator limits the possibility of using weapon, contrary to what seems to be authorized at first sight by the five situations of authorization of the law in the article. The LPDA provision does not make such a restriction.

The absolute character of the necessity of defensive action and the certainty character of proportionality of the means used for defence are in line with the requirements imposed by the case law of the European Court of Human Rights ${ }^{65}$. ECtHR imposes to choose the one that will do the least harm from among the means for the lives of others. In other words, the use of weapons should be ultima ratio. This is considered as a condition in Turkish doctrine as well ${ }^{66}$. If it is not applied as ultima ratio, the absolute necessity condition will not be met ${ }^{67}$. This is the expression of the principle set by the French case law on June 27, 1927 in matters of legitimate defence. In this decision, "legitimate defence is only permitted only to stand an attack off. Because if there is an attack, defence has become necessary. ${ }^{68}$ " As a result of this decision, the necessity character of the defensive action depends above all on the actuality of the act of aggression. For this reason, although the legislator has not imposed a condition of actuality of an aggression for authorize the police to use weapons preventively, considering the "absolute necessity" condition, it is deemed necessary that the probability of an aggression should be quite high. For example, the use of a weapon will not be legitimate, if a person who escapes with the vehicle and does not obey the warning to stop, poses a potential threat to the life or body integrity of law enforcement forces

${ }_{64}$ For the jurisprudence regarding the scope of articles 16/7-b, $\mathrm{c}$ of the LPDA, which allows the law enforcement forces to use of weapons other than legitimate defence, see Mehmet Emin Artuk/ Ahmet Gökcen/ A. Caner Yenidünya, TCK Şerhi Genel Hükümler, $2^{\text {nd }}$ Ed., Ankara, 2014, s. 726 vd.

65 ECtHR, Giuliani and Gaggio v. Italy, GC., 24.03.2011, no 23458/02, § 214; Turkish Court of Cassation 1st Criminal Section 26.04.2012, 2009/756 E. 2012/3273 K. Artuk/Gökcen/ Yenidünya, s. 726.

${ }_{66}$ Tuba Kelep Pekmez, Kolluğun Silah Kullanma Yetkisi, On İki Levha, İstanbul, 2015, p. 127 et al.

${ }^{67}$ The method of the use of weapons in France is expressed as A.M.E.R. Does the aggressor attack (Atteinte) or threaten (Menace) to attack? Is my Environment disponible for using weapon? Finally, is weapon the last resort (ultime Recours)? If the answer "yes" given to these questions, weapon can be used. (Rayne, no. 174)

68 Crim. 27.06.1927, 1929, 1, Recueil Sirey, p. 356. 
or others. The low probability of realizing an aggression, will prevent to evaluate that the weapon to be used against him is absolutely necessary. In such a case, law enforcement forces should avoid to use weapons by targeting individuals. Both the fact that other means to prevent the attack will not remedy (proportionality condition) and the evaluation that there is a sufficiently high probability that the aggression will be realized (necessity condition) makes the use of weapons legitimate.

Decisions on the implementation of the former article L. 2338-3 of the Defence Code regarding the use of weapons by the Gendarmerie in France support the above assessment. The provisions are included in the L. 435-1 article of the CSI today. Indeed, the authorization to the use of weapons given to the gendarmerie by the former article L. 2338-3 of the Defence Code does not allow to exceed reasonable limits. Although the French legislator did not seek the necessity and proportionality conditions in the article similar to the LPDA, by taking into account the decisions of the ECtHR ${ }^{69}$ the Criminal Chamber of the French Court of Cassation sought the absolute necessity and strictly proportionality in matters related to the implementation of the article stipulating the use of weapons by gendarmerie ${ }^{70}$. According to the case law, meeting the conditions of being on duty and wearing the military uniform stipulated in the article does not authorize the gendarmerie to the use of weapons against the driver of the vehicle who does not obey the stop order ${ }^{71}$. The case law seeks the same conditions that legitimate defence sought as a requirement in the exercise of the authority given by the former article $\mathrm{L}$. 2338-3 of the Defence Code.

On February 18, 2003, The Criminal Chamber of French Court of Cassation overturned the decision of the first instance court which upheld the denial of investigation permission in favour of the gendarmerie in accordance

69 ECtHR, McCann and others v. The United Kingdom, GC, 27.09.1995, no 18984/91; ECtHR, Karatepe v. Turkey, 12.10.2010, no 20502/05.

70 Crim. 01.04.2014, no 13-85.519, www.legifrance.gouv.fr (Online 20.04.2021)

71 Crim. 16.011996, no 94-81.585, Criminal Bulletin 1996, no 22; “...gendarmes exercising their action in military uniform are authorized, under the conditions of article 174, to use their weapon to immobilize a vehicle whose driver does not obey the stop orders. However, in this case, the gendarme was acting in civilian clothes, and as he was not in legitimate defence, he could not benefit from the justification of article 174 of the decree. Precision is important. The use of a weapon must remain exceptional. And if the legal conditions are not met, the action accomplished cannot be legitimized." (Bernard Bouloc, "Justification d'une action par l'emploi de la force armée", 1996, RSC, p. 848.) 
with Article 174 of the decree dated 20 May 1903 (which later turned into Article L. 2338-3 of the Defence Code). In its decision, the Court of Cassation referred to the $2^{\text {nd }}$ paragraph of Article 2 of European Convention on Human Rights (ECHR) which states that death is not considered unlawful if it is committed to ensure the defending a person against unlawful violence and to effect the lawful arrest, if it is within the scope of the necessity. The Court of Cassation accepts the authority given by this provision of the Convention only on the condition that it is "absolutely necessary within the framework of the circumstances at the time of the event" 72 . Since this decision, the authority of the gendarmerie to the use of weapons has been subjected the conditions of strictly proportionality and absolute necessity. Although the former article L. 2338-3 of the Defence Code give the gendarmerie the authority to the use of weapons as a preventive manner, the case-law stipulating that these conditions should be complied with, states that the possibility of an act of aggression should be really high. The Court of Cassation approves the lawfulness and irresponsibility arising from authorization of the law based on the former article 2338-3 of the Defence Code, if the regime set by the case law in this field is complied with. In its decision dated March 12, 2013, the Criminal Chamber declared the use of a weapon against the person in the driver's seat is lawful by the reasons states that "stopping the vehicle driver who had committed many serious crimes and did not obey more than one stop order was an absolute necessity for the use of weapons by the gendarmerie, in dangerous conditions for their own security." ${ }^{\text {"73 }}$ In the incident, by the use of weapons the gendarmerie narrowly prevented the fleeing person's vehicle from hitting their own vehicles.

In the light of these decisions, it is seen that the case law implements the possibility of preventive use of weapons engagement in a narrow way for the irresponsibility of the police. The case law accepts justification under the conditions that are very close to legitimate defence within the authority to preventive use of weapons.

72 Crim. 18.02.2003, no 02-80.095, Criminal Bulletin 2003, no 41; Jacques Buisson, “L'usage de l'arme à feu par les gendarmes", 2003, RSC, p. 387.

73 Crim. 12.03.2013, no 12-82.683, Criminal Bulletin 2013, no 63; Crim. 21.10.2014, no 1385.519, www.legifrance.gouv.fr (Online 20.04.2021); Similar to the events in the incident, regarding the use of weapons against those who drove their vehicles on the gendarmerie officers while fleeing and its evaluation within the scope of Article 24/1 of the TCC, see. Turkish Court of Cassation 1st Criminal Section 13.03.2013, 2013/402 E. 2013/2057 K. (Artuk/Gökcen/Yenidünya, p. 730) 
The decisions that deviate from this jurisprudence, which is based on necessity and proportionality, which restrict the use of weapons by the law enforcement forces, cause France to be convicted before the ECtHR. One such example is the Guerdner v. France decision ${ }^{74}$. The shooting by the gendarmerie of a person who achieved to escape while in custody was left unpunished by the French judicial authorities on the basis of the former article L. 2338-3 of the Defence Code. On the occasion of this decision, the ECtHR impose that a lawful arrest does not justify endangering the lives of individuals, except in cases of absolute necessity. In other words, if it is determined that the person who fled while being in custody does not pose a threat to police or others, there is no longer an absolute necessity in terms of using weapons by law enforcement forces in the concrete incident. Although other ways of arrest have been tried, the use of weapons in a fatal way will mean exceeding the limit ${ }^{75}$. Turkey's conviction record on not to comply the proportionality in the use of weapons is worse than France. It can be said that the Court's decisions constituting the case-law on the field of the use of weapons are largely the decisions convicting Turkey ${ }^{76}$. If the circumstances that require the law

74 ECtHR, Guerdner and others v. France, 17.04.2014, no 68780/10.

75 Gildas Roussel, "Il y a force meurtrière excessive dans le fait pour un gendarme de tirer sur un fuyard ne présentant aucune menace pour autrui - Cour européenne des droits de l'homme", 2014, AJ Pénal, p. 359.

76 "The onus was on the authorities to prove that the force used was justified in the circumstances and strictly proportionate in pursuance of one of the aims delineated in the second paragraph of Article 2. They failed to adduce any credible evidence to support either their claim that the deceased was a terrorist or that the security forces had been obliged to retaliate in self-defence in the face of an armed terrorist attack." (ECtHR Kaya v. Turkey, 19.02.1998, no 22729/93, para. 63); "The Court, like the Commission, accepts that the use of force may be justified in the present case under paragraph 2 (c) of Article 2, but it goes without saying that a balance must be struck between the aim pursued and the means employed to achieve it. The gendarmes used a very powerful weapon because they apparently did not have truncheons, riot shields, water cannon, rubber bullets or tear gas. The lack of such equipment is all the more incomprehensible and unacceptable because the province of Sirnak, as the Government pointed out, is in a region in which a state of emergency has been declared, where at the material time disorder could have been expected... In conclusion, the Court considers that in the circumstances of the case the force used to disperse the demonstrators, which caused the death of Ahmet Güleç, was not absolutely necessary within the meaning of Article 2." (Güleç v. Turkey, 27.07.1998, no 21593/93, para. 71-73); "In this regard, it is to be recalled that the text of this provision (see paragraph 68 above), read as a whole, demonstrates that paragraph 2 does not primarily define instances where it is permitted intentionally to kill an individual, but describes the situations where it is permitted to "use force" which may result, as an unintended outcome, in the deprivation of life. The use of the term "absolutely necessary" suggests that a stricter and more compelling test of necessity must be employed from that normally applicable when determining whether 
enforcement forces to the use of weapons are not necessary and proportionate, it will not be seen as a reason for irresponsibility in terms of both the ECtHR and French case law. As a result, in the period of the implementation of former article L. 2338-3 of the Defence Code, the use of weapons regime of the gendarmerie showed a very compatible appearance with the legitimate defence $^{77}$. In the LPDA provisions, no improvement has been made despite all these convictions. While the ECtHR case law is still valid which states if it is determined that the fleeing person does not pose a threat to himself or to others, the law enforcement officers can no longer speak of an absolute necessity in terms of the use of weapons, Article 16/7-(c) of the LPDA which does not seek the actuality of any aggression or threat, is not possible for the law enforcement forces to give permission to the use of weapons in this form. Beyond the conditions required in these clauses, the law enforcement forces should also assess the actuality of an aggression or threat that is sought by national and supra-national case law.

State action is "necessary in a democratic society" under paragraph 2 of Articles 8 to 11 of the Convention. In particular, the force used must be strictly proportionate to the achievement of the aims set out in sub-paragraphs 2 (a), (b) and (c) of Article 2. In keeping with the importance of this provision in a democratic society, the Court must, in making its assessment, subject deprivations of life to the most careful scrutiny, particularly where deliberate lethal force is used, taking into consideration not only the actions of the agents of the State who actually administer the force but also all the surrounding circumstances, including such matters as the planning and control of the actions under examination (see the above-mentioned McCann and Others judgment, p. 46, §\$ 148-50).

Furthermore, under Article 2 of the Convention, read in conjunction with Article 1, the State may be required to take certain measures in order to "secure" an effective enjoyment of the right to life.

In the light of the above considerations, the Court agrees with the Commission that the responsibility of the State is not confined to circumstances where there is significant evidence that misdirected fire from agents of the State has killed a civilian. It may also be engaged where they fail to take all feasible precautions in the choice of means and methods of a security operation mounted against an opposing group with a view to avoiding and, in any event, to minimising, incidental loss of civilian life.

Thus, even though it has not been established beyond reasonable doubt that the bullet which killed Havva Ergi had been fired by the security forces, the Court must consider whether the security forces'operation had been planned and conducted in such a way as to avoid or minimise, to the greatest extent possible, any risk to the lives of the villagers, including from the fire-power of the PKK members caught in the ambush." (Ergi v. Turkey, 28.07.1998, no 23818/94, para. 79).

77 Many authors underline that the regime to be applied to the gendarmerie is also harmonized with other justification facts. See, Jean Pradel/André Varinard, Les grands arrêts du droit pénal général, 10th Ed., Dalloz, 2016, p. 22 ; Dreyer, p. 868-870; Jérôme Millet, "Le droit d'usage des armes des forces concourant à la sécurité intérieure", 2016, Juris-classeur périodique, p. 2257. 
The fact that the use of weapons stipulated by article L. 435-1 of the CSI was subjected to the conditions of absolute necessity and strictly proportionality ${ }^{78}$ shows that the French legislator was also determined to bring the new regime to use weapon in line with legitimate defence. In other words, in the new order, when law enforcement forces use their weapon in circumstances that are very close to legitimate defence, they will be accepted irresponsible by the judicial authorities.

\section{B. Authority to the use of weapons establishes a legitimate defence concept specific to law enforcement forces}

Legitimate defence is a fact of justification in case of an aggression is actual similar to the situations related to the use of weapons by law enforcement forces which are stipulated in both the article 16/7 (a) of the LPDA and the article L. 435-1 of the CSI. The new French regime regulating the law enforcement forces to the use of weapons does not deviate from this point. In case of legitimate defence, defensive action should be necessary and the means used in defence should be proportional to the gravity of the aggression. As we have mentioned above, the French provision subject the use of weapons to these conditions and even reinforced these conditions. At this point, the point that should be especially emphasized is the feature of the aggression. As is known, the aggression must be actual for legitimate defence. When the provisions of both countries regarding the use of weapons are examined, the actuality of the aggression is a matter of discussion ${ }^{79}$. In this respect, it is obvious that justification facts authorization of the law arising from the LPDA 16/7 and the CSI L 435-1, and the legitimate defence are different from each other.

It should be noted again that the main duty of the law enforcement forces are preventive activities and (if the future aggression is not certain) legitimate

78 This situation makes this regime more protective for the right to life and body integrity than the regime stipulated by the former article L. 2338-3 of the Defense Code. (Tzutzuiano, p. 709, ftn. 36).

79 Two schools thus share the issue of the subject, depending on whether the legitimacy of the violence exercised is perceived as a sui generis justification, or on the contrary as falling under the common law of legitimate defence. While the first integrates the specificity of the action of the gendarmerie, and more broadly of any police action, for what it supposes functions or missions inseparable from the public force, the second, on the contrary, wants to be much more reassuring, resulting in subjecting the gendarme or the police to the same conditions of justification as those applicable to any citizen confronted with the need for violence. (Yves Mayaud, "De l'utilisation des armes à feu par les gendarmes: contrainte ou violence?", 1996, RSC, p. 369) 
defence is not very compatible with preventive activities. It's controversial that the preventative acts "riposte anticipée" in article L. 435-1 will be accepted a priori within the framework of legitimate defence ${ }^{80}$. Although there is no aggression yet, there are cases where the existence of a legitimate defence can be accepted. While the article $25 / 1$ of the TCC stipulates the legitimate defence against also a future aggression which will be realized in certainty, the FCC article 122-5 does not obviously stipulates this situation. It is jurisprudence that accepts legitimate defence against imminent aggressions. In the practice of both countries, the fact that an aggression is actual for legitimate defence does not mean that it has to be emerged. Although it has not yet emerged, anticipating this occurrence also justifies the legitimate defence. The level of this possibility is certainty in terms of Turkish law. Considering the French case law, acting with justified assumptions by law enforcement forces as well as for ordinary people, is considered legal ${ }^{81}$. For this reason, the judicial authorities should also consider "how the mental state of the perpetrator was at the time the act was realized in relation to what he knew and predicted what would happen ${ }^{82 ",}$ as well as the actual situation ${ }^{83}$. In this context, "the target of an attack does not have to wait to defend until the first blow is struck to himself. Likewise, in this case the defence will mostly be late and ineffective. The presence of danger is sufficient. " ${ }^{44} \mathrm{As}$ can be seen, according to the French jurisprudence the aggression anticipating to be realized, means the actuality like an ongoing aggression. In the light of what has been told, it can be easily said that the legitimate defence, inherent in the activities of the police not only for standing off, has also a preventive aspect, as it is for everyone ${ }^{85}$.

80 Tzutzuiano, p. 710.

81 For example, in an incident, law enforcement force lonely arrested the thief he was chasing at night in a dark place, but the arrested person resisted with violence during the arrestment. He carried out the arrestment by using weapon and injuring the thief because the accomplice of thief, who was carrying a very dangerous tool for cutting metal fences about a meter in length, could arrive and help at any time. (Paris Court of Appeal 9.10.1978, 1979, II, JCP, p. 19232, note Pierre Bouzat.)

82 See Crim. 9.09.2015, no 14-81.308, www.legifrance.gouv.fr (Online 20.04.2021); Corrine Mascala, "Faits justificatifs - Légitime défense", in J.-Cl. Pénal Code, LexisNexis, 2017, no 44.

83 Likewise, a law enforcement force using his weapon, was accepted irresponsible due to legitimate defence, who is faced with all the indications that a dangerous criminal will shoot. (Ibid, no 27).

84 Émile Garçon, Code pénal annoté, volume 1, art. 328, p. 818.

85 Tzutzuiano, p. 710; Décima, "Légitime réforme?", p. 2527 
As a matter of fact, legitimate defence and authorization of the law are not obviously differentiated in terms of actuality condition, especially when the police use weapon. Unlike the French provision, although the LPDA does not stipulate the necessity and proportionality as common conditions for engagement to the use of weapons, these conditions are indispensable conditions for the use of weapons directed towards the right to life and body integrity. The article L. 435-1 has already been legislated at the end of the processes described above in a way that allows the law enforcement forces to use of weapons in the actuality of an aggression even it is probable against itself or someone else within the absolute necessity and strictly proportionality conditions. Unless the jurisprudence on the authorization to the use of weapons, which is a typical authorization of the law provision, does not consider the probability of an offensive act in a wider concept, this act of the law enforcement force using his weapon causes his irresponsibility in conditions that are very close to legitimate defence beyond the authorization of the law. Considering the ECtHR's jurisprudence in which absolute necessity circumstances are accepted, a possible large consideration in this direction seems to be difficult ${ }^{86}$.

In the context of authorization of the law, it is necessary to specially evaluate the engagements stipulated in Article L. 435-1 paragraph (5) and LPDA Article 16 / 7- (d). In both provisions, unlike other engagements, the use of weapon is stipulated in response to a hypothetical crime. Likewise, in the French provision, in this engagement, the law enforcement forces are given the authority to the use of weapons in order to prevent the possible repetition of one or more murder or attempting to murder. According to Tzutzuiano, considering this provision, it refers to the cases other than those that are included within the scope of legitimate defence ${ }^{87}$. As an opposite opinion, the provision deviates from legitimate defence. However, considering the sheer number of conditions the legislator subjects for the implementation of this provision, "it does not seem to add much in terms of expanding the concept of

86 François Fourment, "La loi no 2017-258 du 28 février 2017 relative à la sécurité publique dans ses aspects de droit pénal”, 2017, 5, Dr. penal, p. 11.

87 Tzutzuiano, p. 711 (The author claim that the definition in the relevant provision also means the putative legitimate defence. We cannot agree with this view. The provision in article $\mathrm{L}$ 435-1 clause 5 is emphasizing the probability of the aggression. Probable aggression is not in the scope of actuality condition of legitimate defence. As expressed above, the provision of the clause defines the situation as a condition of lawfulness, that is considered as mistake in terms of legitimate defence.) 
legitimate defence. ${ }^{88 "}$ As regulated by the legislator, law enforcement forces can only use weapon to prevent in the upcoming period, the repetition of one or more murder or attempted murder that have just happened, in case of there are objective and real reasons at the time he used his weapon that will lead him to think that this repetition is possible. In other words, law enforcement forces can only use weapons if there are "objective and real reasons" that will lead him that the aggression is likely to be repeated within the framework of the "information at the time of using weapon". The fact that the law enforcement force is facing a person who has murdered or attempted to murder one or more people is not sufficient reason to use his weapon. Adequate conditions for using weapons within the scope of the fifth paragraph have not yet been met. Even if the law enforcement force knows that the person has committed these acts, this is not adequate reasons for using weapons. Law enforcement force should have sufficient information based on objective and real reasons that this person will repeat these acts. The weapon can exclusively be used to prevent this possibility. The multiplicity of the stipulated conditions requires that the irresponsibility of the police who used his weapon can only be accepted in case of the probability of this repetition reaches a very high level ${ }^{89}$. Law enforcement forces must have the knowledge that the person has committed these acts. Not enough, in addition to this knowledge he must be predicting that the offender will repeat these acts. This is not enough too, there must be objective and real reasons that will cause him to predict this. That is, for example, the person may have explosive materials on or near.

It is also possible to read that the text reveals a broad concept of the probability of repetition of the crime, considering all the conditions stipulated by the provision as one and the same condition ${ }^{90}$. In other words, the presence of a person who has just murdered or attempted to murder one or more people

\footnotetext{
88 Décima, "Légitime réforme?", p. 2527; According to Parizot, the provision risks to cause scrambling the case law on the use of weapons by law enforcement forces. (Raphaële Parizot, "La loi du 3 juin 2016: aspects obscurs de droit pénal général”, 2016, RSC, p. 380). In the concrete French case law, the limits of this authority is highly stricted by respecting the case law of ECtHR. See (Crim. 18.02.2003, no 02-80.095, 2003, RSC, p. 387, obs Jacques Buisson; Crim. 27.02.2008, no 07-88.470 ; Crim. 01.04.2014, no 13-85.519, 2015, D, p. 110, chron. Gildas Barbier, Benoît Laurent, Géraldine Guého, Thierry Azéma; Crim. 21.10.2014, no 13-85.519, 2015, D, p.110, chron. Gildas Barbier, Benoît Laurent, Géraldine Guého, Thierry Azéma; ECtHR, Guerdner and others v. France, 17.04.2014, no 68780/10, para. 69.

89 Tzutzuiano, p. 711.

$90 \quad$ Parizot, p. 381.
}

898 Ankara Hacı Bayram Veli Üniversitesi Hukuk Fakültesi Dergisi C. XXV, Y. 2021, Sa. 2 
may be an objective and real reason for the law enforcement force who will use his weapon to think that the repetition of these actions is possible and thus legitimizes the use of weapons ${ }^{91}$. The same interpretation can be done in terms of article 16/7-d of LPDA. The engagement which is stipulated in the clause (d) is actually nothing more than legitimate defence. Beyond the legitimate defence the clause counts a number of means of attack. In other words, the existence of these means of attack near or on someone is a kind of legitimate defence presumption. According to this kind of interpretation of the clause, although there will not be an aggression, law enforcement force can consider the presence of person carrying these means as a sufficient reason to use of weapons. It is not an unpredictable possibility for the police to resort to his weapon at the moment he sees a person with molotov cocktail.

The interpretation that the presence of a person with molotov cocktail is accepted as a sufficient reason to use of weapons or presence of a person who has committed one or more acts of murder or attempting to murder is accepted as a real and objective reason for the repetition of these acts and in this way it causes the irresponsibility of the law enforcement force who used his weapon, is undoubtedly beyond the concept of legitimate defence. Obviously, it is very difficult to interpret it this way ${ }^{92}$. Likewise, the French provision was previously stipulated in Article 122-4-1 of the FCC in connection with the justification fact authorization of the law. Later, it was stipulated as the fifth clause after the first four clauses of article L. 435-1. Considering that the first four clauses are strictly included in the concept of legitimate defence and subjected to the necessity and proportionality which are common conditions for all clauses, it is difficult to say that the fifth clause is outside the concept of legitimate defence. How the texts are interpreted depends on also where they are regulated within the laws. Such an interpretation is less unfounded in the period when it was stipulated as Article 122-4-1, but rather unfounded considering that it was subsequently stipulated under Article L. 435-1 of the CSI. Since there is no case law regarding the implementation of paragraph 5 of Article L. 435-1 and no adequate case law regarding the implementation of

91 Ibid. While talking about this possibility, the author says, "It should be worried that..." can be interpreted in such a way.

92 The decision in an opposite vein see, ECtHR, GC, Armani Da Silva v. United Kingdom, 30.03.2016, no 5878/08, concerning the case in which, following the terrorist attacks in London in 2005, a Brazilian national had been shot by mistake, in the London Underground, by law enforcement forces, who had been able to have "honest and genuine belief that the use of force was necessary", by a "subjective reasonableness" para. 251 et al. 
LPDA Article 16/7-d, it is difficult to say with this certainty that the provision will be implemented in this way.

\section{Conclusion}

Although the TCC defines the term of weapon very broadly, the term weapon refers to fire weapons in the context of the police's authority to the use of weapons. The use of fire weapons conflicts with the right to life and body integrity which are protected by constitutions and supranational texts. In this respect, the authority to the use of weapons should be exercised under conditions as close to legitimate defence as possible.

The attacks that took place in France in 2015 and 2016 caused the national police's authority to use weapons to be discussed. It was assessed that the authorities of the national police were insufficient to prevent these attacks. Events that took place in Turkey in 2014, have led to a modification in the provisions related to the authority to the use of weapons. France has established a single framework law for each type of law enforcement forces. Accordingly, law enforcement forces are authorized to use weapons under five different engagements. The first four engagements are worded with a method that defines legitimate defence. However, these four engagements do not specifically mention the condition of actuality. The fifth engagement, on one hand, mentions the condition of actuality, on the other hand, unlike the legitimate defence concept, it deliberately preferred the "approaching" time expression instead of the "imminent" time expression as a time indicator.

The fact that the French provision treats the actuality condition different from the usual understanding of the concept of legitimate defence, can be interpreted as the police can use weapons other than legitimate defence. The ECHR also authorizes that the right to life can be restricted other than legitimate defence. Constitution of Turkish Republic is also in the same vein. In addition, article 16/7 of the LPDA, which is the basic text related to the authorization of the police to the use of weapons, stipulates that the law enforcement forces can use weapons other than legitimate defence.

Although the relevant provisions open the door to the use of weapons other than legitimate defence, the decisions of the ECtHR on the subject, emphasize the conditions of absolute necessity and strictly proportionality. Additionally, the French provision subjected all five engagements to the common conditions of absolute necessity and strictly proportionality. Subjecting such conditions is a much stricter regime than the legitimate defence regulation of the FCC. Namely, it tightens the necessity and proportionality conditions while loosening the condition of actuality. Additionally, the inevitable mistake of 
the law enforcement forces is included in the scope of lawfulness under the fifth engagement.

The Turkish provision do not subject the engagements of the use of weapons to common conditions of necessity and proportionality. Article 16/7 of the LPDA considers the legitimate defence as the first engagement. Apart from that, by stipulating other engagements, it has implicitly granted the authority to the use of weapons in situations other than legitimate defence. However, the authorization in clause (b), is a prerequisite for using weapons rather than an engagement. Authority in clause (d) is a definition within the concept of legitimate defence. But beyond the legitimate defence, counting the number of means of attack can be falsely interpreted as a presumption of legitimate defence. So the police may consider the presence of a person with molotov as the meeting of the conditions of the use of weapon.

The main controversy in terms of our study, is the use of weapons within the engagement in clause (c). It is also maintained in the Turkish doctrine (in accordance with the provision) that the law enforcement force can use weapons if they are not able to arrest the individual otherwise. However, it is very difficult to stay in the limits of proportionality to arrest while the individual is running away. Accordingly, police often exceed the limits and kill the suspect and this situation causes many convictions in the decisions of Turkish Court of Cassation and convictions of Turkey before ECtHR

The new regime of the use of weapons in France shows that the law enforcement forces' preventive activities by using weapons requires evaluating the condition of actuality in a specific concept to law enforcement forces. However, these authorities related to preventive activities must be performed necessarily and proportionately. If law enforcement forces believe by the reasonable information that the conditions for the use of weapons are met, the legislation should resolve their hesitations. On the contrary, legislation should not encourage the use of weapons in situations such as in LPDA article $16 / 7-\mathrm{c}$ which is unrelated to legitimate defence. In this way, the legislation per se allows violations of the right to life and body integrity. Instead, it should be authorized to the use of weapons in possibilities where the fleeing person attacks himself or someone else under conditions very close to the concept of legitimate defence. In our opinion, in context with authorization of the law, the use of weapons by the law enforcement forces is a legitimate defence concept specific to law enforcement forces. In this concept, necessity, proportionality and the actuality conditions are specially evaluated by taking the activities carried out by the law enforcement forces into account. 


\section{Bibliography}

Artuk M E/Gökcen A/Alşahin M E/ Çakır K, Türk Ceza Hukuku Genel Hükümler, 14th Ed., Adalet Yayınevi, Ankara, 2020.

Artuk M E/Gökcen A/Yenidünya A C, TCK Şerhi Genel Hükümler, 2nd Ed., Ankara, 2014.

Barbier G, “Art. 122-3: Erreur sur le droit”, in J.-Cl. Pénal Code, LexisNexis.

Bernardini R, "Légitime defense", in Répertoire de droit pénal et de procédure pénale, Dalloz.

Bouloc B, “Autorisation de la loi. Admission. Portée”, 2000, Revue de Science Criminelle et de Droit Pénal Comparé.

Bouloc B, "Justification d'une action par l'emploi de la force armée", 1996, Revue de Science Criminelle et de Droit Pénal Comparé.

Bouloc B, Droit pénal général, 25th Ed., Dalloz, Paris, 2017.

Buisson J, "L'usage de l'arme à feu par les gendarmes", 2003, Revue de Science Criminelle et de Droit Pénal Comparé.

Buisson J, "Nécessité et proportionnalité dans l'usage de l'arme à feu", 2006, Revue de Science Criminelle et de Droit Pénal Comparé.

Buisson J, L'acte de police, volume II, Lyon, 1988.

Décima O, “Légitime réforme?”, 2016, Recueil Dalloz.

Décima O, “Terreur et métamorphose - À propos de la loi no 2016-731 du 3 juin 2016 sur la lutte contre le terrorisme”, 2016, Recueil Dalloz.

Dreyer E, Droit pénal general, 4th Ed., LexisNexis, Paris, 2016.

Eryılmaz M B/Bozlak A, "Hukukumuzda Zor Ve Silah Kullanma Yetkisi", 2009, 83, TBB Dergisi.

Flauss J-F, "Actualité de la Convention européenne des droits de l'homme" (août 2004 - janv. 2005), 2005, Actualité juridique droit administrative.

Fourment F, "La loi no 2017-258 du 28 février 2017 relative à la sécurité publique dans ses aspects de droit pénal”, 2017, 5, Dr. Penal.

Garçon E, Code pénal annoté, volume 1.

Göktürk N, "Hukuka Uygunluk Nedenlerinin Maddi Koşullarında Yanılgının Hukuki Niteliği”, 2014, 26, Ceza Hukuku Dergisi. 
Hafızoğulları Z/Özen M, Türk Ceza Hukuku, Genel Hükümler, 12th Ed., Seçkin, Ankara, 2019.

Institut national des hautes études de la sécurité et de la justice, "Le cadre legal de l'usage des armes par les forces de sécurités", Rapport of Mission chaired by Hélène Cazaux-Charles, 2017.

Janel G, "La nouvelle loi n²017-258 du 28 février 2017 relative à la sécurité intérieure publique a créé un article L.435-1 du Code de la sécurité intérieure définissant un nouveau cadre légal d'usage des armes", 2019, Centre National de la Fonction Publique Territoriale (CNFPT).

Jean Pradel/André Varinard, Les grands arrêts du droit pénal général, 10th Ed., Dalloz, Paris, 2016.

Kangal Z T, "Ceza Hukukunda Hukuka Uygunluk Nedeni Olarak Kanun Hükmünün Yerine Getirilmesi”, 2012, 89-90, Bahçeşehir Üniversitesi Hukuk Fakültesi Kazancı Hakemli Hukuk Dergisi.

Kelep Pekmez T, Kolluğun Silah Kullanma Yetkisi, On İki Levha, İstanbul, 2015.

Koca M/Üzülmez İ, Türk Ceza Hukuku Genel Hükümler, 13th Ed., Seçkin, Ankara, 2020.

Mascala C, "Faits justificatifs - Etat de nécessité", in J.-Cl. Pénal Code, LexisNexis, 2016.

Mascala C, "Faits justificatifs - Légitime défense", in J.-Cl. Pénal Code, LexisNexis, 2017.

Mayaud Y, "De l'utilisation des armes à feu par les gendarmes: contrainte ou violence?", 1996, Revue de Science Criminelle et de Droit Pénal Comparé.

Mayaud Y, "Violences mortelles par un gendarme, ou d'une justification de transition", 2018, Revue de Science Criminelle et de Droit Pénal Comparé.

Millet $\mathrm{J}$, "Le droit d'usage des armes des forces concourant à la sécurité intérieure", 2016, Juris-classeur périodique.

Murbach-Vibert M, "Attroupement", in Répertoire de droit pénal et de procédure pénale, Dalloz.

Özgenç İ, Türk Ceza Hukuku Genel Hükümler, 16th Ed., Seçkin Yayınları, Ankara, 2020. 
Parizot R, "La loi du 3 juin 2016: aspects obscurs de droit pénal général”, 2016, Revue de Science Criminelle et de Droit Pénal Comparé.

Pradel J, "Pour une légitime défense spécifique aux membres des forces de l’ordre”, 2016, Recueil Dalloz.

Pradel J, Droit pénal comparé, 4th Edition, Dalloz, Paris, 2016.

Pradel J, Droit pénal général, 21st Ed., Cujas, Paris.

Rassat M-L, Droit pénal général, 4th Ed., Ellipses, Paris, 2017.

Rayne S, "Gendarmerie", in Répertoire de droit pénal et de procédure pénale, Dalloz.

Roussel G, "Il y a force meurtrière excessive dans le fait pour un gendarme de tirer sur un fuyard ne présentant aucune menace pour autrui - Cour européenne des droits de l'homme", 2014, AJ Pénal.

Sözüer A, Türk Ceza Hukuku Mevzuatı, Alfa Yayınları, 4th Ed., İstanbul, 2015.

Tzutzuiano C, "L'usage des armes par les forces de l'ordre", 2017, 4, Revue de Science Criminelle et de Droit Pénal Comparé.

Viriot-Barrial D, "Erreur sur le droit", in Répertoire de droit pénal et de procédure pénale, Dalloz.

\section{Online Sources.}

https://hudoc.echr.coe.int

https:/juridique.defenseurdesdroits.fr

https://www.cncdh.fr

https://www.legifrance.gouv.fr

https://www.setav.org

www.anayasa.gov.tr

www.assemblee-nationale.fr

www.dalloz.fr

www.lexis360.fr 